\begin{tabular}{ccc} 
Tersedia online di: http://ejournal-balitbang.kkp.go.id/index.php/jppi & JURNAL \\
e-mail:jppi.puslitbangkan@gmail.com & PENELITIAN \\
PERIKANAN & INDONESIA \\
JURNAL PENELITIANPERIKANANINDONESIA & Volume 24 Nomor 1 Maret 2018 \\
p-ISSN: 0853-5884 & e-ISSN: 2502-6542 \\
Nomor Akreditasi: 653/AU3/P2MI-LIPI/07/2015 & \\
\hline
\end{tabular}

\title{
STRUKTUR UKURAN DAN BIOLOGI POPULASI RAJUNGAN (Portunus pelagicus Linnaeus, 1758) DI PERAIRAN KEPULAUAN ARU
}

\section{SIZE STRUCTURE AND POPULATION BIOLOGY OF BLUE SWIMMING CRABS (Portunus pelagicus Linnaeus, 1758) IN THE WATERS OF KEPULAUAN ARU}

\author{
Duranta D. Kembaren ${ }^{\star 1}$ dan Adi Surahman ${ }^{1}$ \\ Balai Riset Perikanan Laut, Komplek Raiser Jln. Raya Bogor KM. 47 Nanggewer Mekar Cibinong, Jawa \\ Barat-16912, Indonesia \\ Teregistrasi I tanggal: 22 Juni 2017; Diterima setelah perbaikan tanggal: 19 Februari 2018; \\ Disetujui terbit tanggal: 21 Februari 2018
}

\begin{abstract}
ABSTRAK
Penelitian struktur ukuran dan biologi populasi rajungan di perairan Kepulauan Aru telah dilakukan pada Januari-April, Juni dan Agustus-November 2016. Penelitian ini bertujuan untuk mengidentifikasi struktur ukuran dan biologi populasi yang meliputi pertumbuhan, laju kematian, dan tingkat eksploitasi rajungan. Pemahaman struktur ukuran dan biologi populasi dapat dijadikan dasar masukan untuk pengelolaan perikanan. Rata-rata ukuran lebar karapas rajungan yang tertangkap sebesar $136 \mathrm{~mm}$ untuk jantan dan $141 \mathrm{~mm}$ untuk betina. Rajungan yang tertangkap pada Januari dan Juni memiliki rata-rata ukuran yang lebih besar. Rata-rata rajungan yang tertangkap sudah melawati ukuran matang gonad $(\mathrm{Lc}=133,4 \mathrm{~mm}>\mathrm{Lm}=119,9 \mathrm{~mm})$. Puncak musim pemijahan terjadi pada Februari-Maret dan Agustus-September. Lebar karapas asimtosis $(\mathrm{CW} \infty)$ sebesar $185 \mathrm{~mm}$ dengan laju pertumbuhan $(\mathrm{K})$ 1,15 tahun ${ }^{-1}$ serta laju kematian total $(\mathrm{Z})$ 4,94 tahun $^{-1}$, laju kematian alamiah (M) 1,20 tahun $^{-1}$ serta laju kematian akibat penangkapan (F) 3,74 tahun $^{-1}$. Laju eksploitasi sudah berada pada kondisi lebih tangkap $(E=0,76)$. Hasil kajian menyarankan bahwa pengelolaan perikanan rajungan perlu dilakukan secara hati-hati agar sumberdaya ini dapat lestari. Salah satu upaya yang dapat di tempuh adalah dengan menerapkan sistem penutupan musim penangkapan rajungan pada saat terjadinya puncak musim pemijahan yaitu pada Februari-Maret dan Agustus-September. Dengan demikian diharapkan proses regenerasi dan rekrutmen rajungan selalu dapat mendukung ketersedian stok sumberdaya rajungan di perairan Kepulauan Aru ini.
\end{abstract}

Kata Kunci: Biologi; Kepulauan Aru; populasi; rajungan

\begin{abstract}
Study on the size structure and population biology of blue swimming crab in the waters of Kepualuan Aru was conducted in January to April, June and August to November 2016. The aim of this study was to identify the size structure and population biology i.e. growth, mortality, and exploitation rate of blue swimming crab. Understanding on the size structure and population biology can be used as basic information for managing blue swimming crab fisheries. Average size of carapace width of blue swimming crab was $136 \mathrm{~mm}$ for male and $141 \mathrm{~mm}$ for female. Catch on January and June was bigger size than others months. Length at first capture was higher than length at maturity $(L c=133,4 \mathrm{~mm}>L m=119,9 \mathrm{~mm})$. Spawning peak season occurs in FebruaryMarch and August-September. Asymptotic carapace width (CW $\infty$ ) of blue swimming crab was 185 $\mathrm{mm}$ with the growth rate $(K)$ was 1,20 year $^{1}$, total mortality $(Z)$ was 4,94 year ${ }^{1}$, natural mortality $(M)$ was 1,20 year ${ }^{1}$, and fishing mortality $(F)$ was 3,74 year ${ }^{1}$. Exploitation rate was exceed the sustainability limit $(E=0,76)$. Thus, it is needed to manage the blue swimming crab fishery with
\end{abstract}

Korespondensi penulis:

dd.kembaren@gmail.com 
precautionary approach. Based on this study, we suggest to apply the fishing closure system at the peak of spawning season. Thus, the regeneration process and recruitment will support the availability of blue swimming crabs resource in Kepualuan Aru waters.

\section{Keywords: Biology; blue swimming crab; Kepulauan Aru waters; population}

\section{PENDAHULUAN}

Rajungan termasuk dalam kelompok kepiting perenang (Portunidae) yang merupakan bagian Krustase dari kelas Malacostraca dan ordo Decapoda. Decapoda pada umumnya telah banyak menjadi objek penelitian karena mempunyai nilai ekonomis tinggi dan keragaman jenis yang cukup banyak (Martin \& Davis 2001). Sebaran rajungan (Portunus pelagicus) meliputi perairan pantai tropis di sepanjang Samudera Hindia bagian barat, Timur Samudera Pasifik dan Indo Pasifik barat (Kailola et al., 1993; Ng, 1998). Wilayah perairan bagian Pasifik Barat salah satunya adalah perairan Laut Aru dan Kepulauan Aru. Produksi rajungan di statistik kabupaten Kepulauan Aru baru tercatat mulai dari tahun 2014 dengan produksi 6,2 ton dan meningkat menjadi 9,9 ton pada tahun 2015 . Produksi rajungan di daerah ini tergolong rendah dibandingkan dengan jenis krustase lainnya seperti udang dan kepiting bakau dimana kontribusi rajungan hanya sekitar 5-10\% dibandingkan udang dan kepiting (DKP Kepulauan Aru, 2012-2016).

Namun demikian, pemanfaatan rajungan di perairan Kepulauan Aru yang dilakukan secara terus menerus tanpa ada pengelolaan tentunya akan membawa pada terjadinya degradasi stok sumberdaya. Kajian biologi populasi rajungan dapat memberikan informasi bagaimana respon stok sumberdaya rajungan terhadap aktivitas penangkapan sehingga dapat diketahui kondisi stok sumberdaya rajungan di perairan tersebut. Dengan mengetahui kondisi stok sumberdaya seperti dinamika populasi, maka tindakan pengelolaan dapat dilakukan untuk menjaga kelestarian sumberdaya (King 1995). Indikator dinamika populasi sering digunakan sebagai pertimbangan dalam pengelolaan perikanan karena lebih responsif terhadap tingkat eksploitasi dan kondisi lingkungan (Beddington \& Kirkwood, 2005; Morgan, 2008).

Kajian tentang stok rajungan di perairan Indonesia telah cukup banyak dilakukan diantaranya yaitu di perairan Mayangan (Hermanto, 2004), perairan Brebes (Sunarto, 2012), perairan Teluk Bone (Kembaren et al., 2012), perairan Pati (Ernawati et al., 2014), perairan Belitung (Ernawati et al., 2015), perairan Timur Lampung (Zairion et al., 2014a; Zairion et al., 2014b; Zairion et al., 2015), dan perairan Teluk Lasongko (Hamid et al., 2016). Kajian-kajian tersebut terkait dengan pertumbuhan, reproduksi, dinamika populasi serta status stok. Namun demikian, kajian penelitian tentang kondisi stok sumberdaya rajungan dari perairan Kepulauan Aru belum pernah dilakukan sebelumnya. Oleh karena itu, penelitian ini dirasa sangat perlu untuk dilakukan agar dapat diketahui informasi biologi populasi rajungan di perairan Kepulauan Aru ini.

Penelitian ini bertujuan untuk mengidentifikasi struktur ukuran, musim pemijahan dan biologi populasi yang meliputi pertumbuhan, laju kematian, tingkat eksploitasi rajungan. Hasil kajian ini diharapkan dapat dijadikan sebagai bahan dasar masukan untuk pengelolaan perikanan rajungan yang berkelanjutan di perairan Kepulauan Aru.

\section{BAHAN DAN METODE Pengumpulan Data}

Pengukuran biometrik dan pengamatan biologi rajungan (Portunus pelagicus) dilakukan selama 9 bulan pada tahun 2016 yaitu pada Januari-April, Juni dan Agustus-November. Contoh rajungan diperoleh dari hasil tangkapan sero dan tangkapan jaring insang yang didaratkan di Dobo. Diperoleh rajungan yang dijadikan contoh sebanyak 150 - 200 ekor setiap bulan pengamatan. Parameter yang diukur dan diamati meliputi lebar karapas (carapace width, CW), bobot, jenis kelamin, dan tingkat kematangan gonad. Lebar karapas rajungan ditentukan dengan mengukur jarak antara duri terpanjang pada kedua sisi karapas menggunakan jangka sorong. Bobot individu rajungan diukur dengan timbangan digital dengan ketelitian 1 gram. Penentuan jenis kelamin dilakukan secara visual dengan mengamati pola pada bagian abdomennya. Kematangan gonad ditentukan berdasarkan kriteria Sumpton et al., (1994), sebagai berikut: tingkat kematangan gonad (TKG) 1 dicirikan dengan belum terlihatnya tanda-tanda secara makroskopis; TKG 2 (gonad immature) dicirikan dengan gonad yang berwarna putih transparan; TKG 3 (gonad maturing) dicirikan dengan gonad yang sudah berwarna kuning/oranye muda namun belum menyebar ke dalam area hati; TKG 4 (gonad mature) dicirikan dengan gonad berwarna oranye terang dan tersebar hingga ke area hati; dan TKG 5 (ovigerous) yaitu ketika secara eksternal betina mengerami telurtelur yang telah dibuahi di bagian abdominal flap. 


\section{Analisis Data}

Sebaran frekuensi lebar karapas diperoleh dengan mentabulasikan data lebar karapas dalam tabel distribusi frekuensi dengan selang kelas $5 \mathrm{~mm}$. Pendugaan ukuran matang gonad (length at maturity/Lm) dengan pendekatan fungsi logistik (King, 1995) dengan persamaan:

$$
P_{L m}=\frac{1}{1+\exp (a L+b)}
$$

dimana $P_{L m}$ adalah proporsi rajungan dengan lebar karapas $L$ yang telah matang telur dibagi jumlah rajungan dengan lebar karapas $L$ yang telah matang dan belum matang; a dan b adalah parameter kurva $(a<0$ dan $b>0)$, sehingga panjang pada $50 \%$ matang (Lm) adalah sama dengan $-\mathrm{a} / \mathrm{b}$.

Penghitungan rata-rata ukuran rajungan pertama kali tertangkap (Lc) menggunakan pendekatan selektivitas celah pelolosan dengan fungsi logistik (Spare \& Venema 1999) dengan persamaan:

$$
S_{L C}=\frac{1}{1+\exp (a L+b)}
$$

dimana $S_{L c}$ adalah rajungan dengan lebar karapas $L$ yang tertahan pada alat tangkap dibagi dengan lebar karapas $\mathrm{L}$ yang tidak tertangkap; $a$ dan $b$ adalah parameter kurva $(a<0$ dan $b>0)$, sehingga panjang pada $50 \%$ tertangkap (Lc) adalah sama dengan $-a / b$.

Penentuan lebar karapas asimtotis $\left(\mathrm{CW}_{\infty}\right)$ dan koefisien pertumbuhan (K) diduga dengan menggunakan program Electronic Length Frequency Analysis (ELEFAN) yang dikemas dalam perangkat lunak FiSAT II (Gayanilo et al., 2005). Laju mortalitas alamiah (M) diduga melalui persamaan empiris Pauly
(1983) yang menggunakan data rata-rata suhu permukaan perairan tahunan ( $\mathrm{T}$ ) sebagai berikut:

$\begin{aligned} \log (M)= & -0,0066-0,279 \log C W \infty+0,6543 \log K \\ & +0,4634 \log T \ldots \ldots \ldots \ldots \ldots \ldots \ldots \ldots \ldots \ldots \ldots \ldots \ldots \ldots \ldots \ldots \ldots\end{aligned}$

dimana $\mathrm{M}=$ mortalitas alami $\left(\operatorname{tahun}^{-1}\right), \mathrm{CW}_{\infty}=$ lebar karapas asimtosis rajungan $(\mathrm{mm}), \mathrm{K}=$ laju pertumbuhan $\left(\right.$ tahun $\left.^{-1}\right), T=$ rata-rata suhu perairan di lokasi sampling $\left(29^{\circ} \mathrm{C}\right)$.

Pendugaan mortalitas total $(Z)$ dilakukan dengan metode kurva konversi hasil tangkapan dengan panjang (length-converted catch curve) pada paket program FiSAT II (Pauly, 1983; Gayanilo et al., 2005). Mortalitas penangkapan (F) dan laju eksploitasi (E) dihitung dengan rumus (Pauly, 1983):

$F=Z-M$ dan $E=F / Z$

dimana, $\mathrm{F}=$ mortalitas penangkapan $\left(\right.$ tahun $\left.^{-1}\right), \mathrm{Z}$ $=$ mortalitas total $\left(\right.$ tahun $\left.^{-1}\right), \mathrm{E}=$ laju eksploitasi .

\section{HASIL DAN BAHASAN \\ Hasil}

\section{Sebaran Ukuran}

Sebaran ukuran lebar karapas (CW) rajungan jantan yang tertangkap selama penelitian berkisar antara 92,5 - $183 \mathrm{~mm}$ dengan lebar karapas rata-rata $136 \mathrm{~mm}( \pm 15,5)$. Pada rajungan betina berkisar antara 92,5 - $181 \mathrm{~mm}$ dengan lebar karapas rata-rata 141 $\mathrm{mm}( \pm 16)$ (Gambar 1). Pada Gambar 1 terdapat 3 modus yang mencerminkan kelompok ukuran rajungan yang tertangkap. Puncak modus pada rajungan jantan dan betina tidak berbeda yaitu pada ukuran lebar karapas $140 \mathrm{~mm}$ dan berkisar antara $130-150 \mathrm{~mm}$.

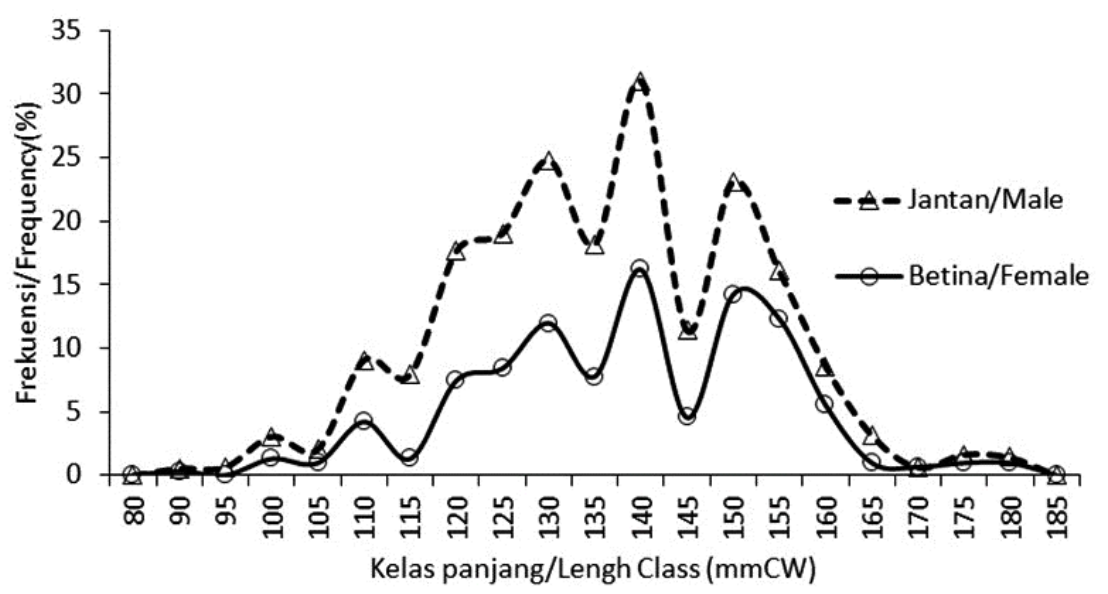

Gambar 1. Sebaran frekuensi lebarkarapas rajungan (Portunus pelagicus) tertangkap di perairan Kepulauan Aru, 2016. Figure 1. Length frequency distribution of blue swimming crab (Portunus pelagicus) caught in Kepualuan Aru waters, 2016. 
Sebaran struktur ukuran lebar karapas dan berat rajungan secara temporal tanpa membedakan jenis kelamin disajikan pada Gambar 2. Rata-rata ukuran lebar karapas rajungan yang tertangkap setiap bulan pengamatan berkisar antara 132,6-146,5 mm dengan

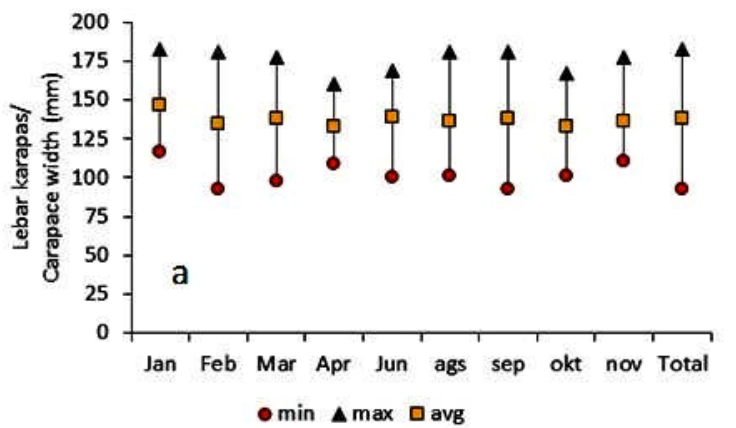

rata-rata bulanan sebesar 137,8 $\mathrm{mmCW}$. Rata-rata lebar karapas pada Januari dan Juni lebih besar dibandingkan bulan-bulan lainnya. Variasi lebar karapas cenderung lebih lebar pada Februari dan September dan sempit pada April dan November.

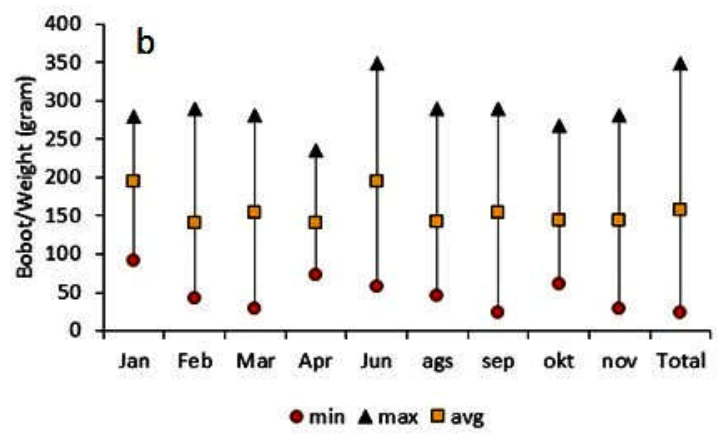

Gambar 2. Struktur ukuran lebar karapas (a) dan bobot (b) rajungan (Portunus pelagicus) secara bulanan di perairan Kepulauan Aru, 2016.

Figure 2. Monthly carapace width (a) and weight (b) structure of blue swimming crab (Portunus pelagicus) in Kepulauan Aru waters, 2016.

Sebaran struktur berat individu rajungan secara temporal menunjukkan bahwa rata-rata bobot individu rajungan pada bulan-bulan pengamatan berkisar antara 140,3 - 195,4 g dengan rata-rata bulanan sebesar $157,3 \mathrm{~g}$. Bobot rata-rata rajungan yang tertangkap pada Januari dan Juni lebih tinggi dibandingkan bulan-bulan lainnya. Variasi bobot individu rajungan lebar pada Juni dan sempit pada April.

\section{Rata-rata Ukuran Tertangkap, Rata-rata Ukuran Matang Gonad, dan Musim Pemijahan}

Rata-rata ukuran lebar karapas rajungan yang tertangkap (Lc) di perairan Kepulauan Aru sebesar $133,4 \mathrm{~mm}$. Analisa terhadap rajungan betina menunjukkan rata-rata mencapai ukuran matang kelamin (Lm) pada lebar karapas 119,9 mm (Gambar

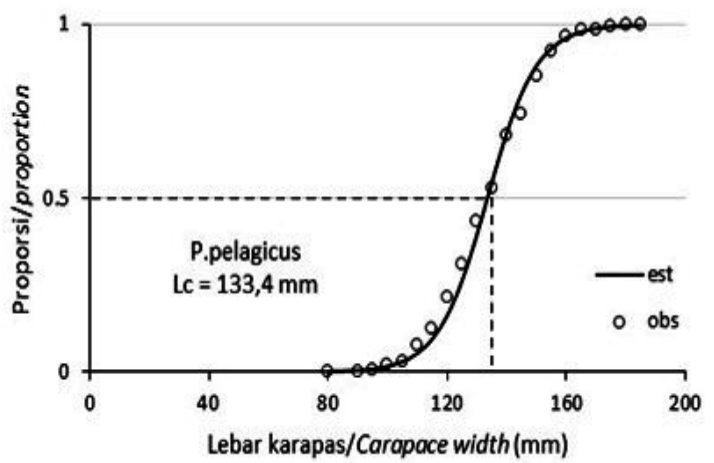

3). Hasil ini menunjukkan bahwa rata-rata ukuran rajungan yang tertangkap lebih besar daripada ukuran pada saat mencapai kematangan gonad ( $L c>L m)$.

Hasil penelitian menunjukkan bahwa rajungan cenderung mengalami pemijahan sepanjang tahun yang ditunjukkan dengan ditemukannya rajungan betina yang matang gonad setiap bulan pengamatan. Namun demikian terdapat puncak dimana persentase rajungan betina yang membawa telur (eggs berried female) lebih tinggi dibanding bulan-bulan pengamatan lainnya. Puncak musim pemijahan rajungan di perairan ini terjadi pada Februari-Maret dan Agustus-September, yang ditunjukkan dengan persentase rajungan betina yang matang gonad (mature) dan membawa telur (berried) yang lebih tinggi dibanding bulan-bulan pengamatan lainnya (Gambar 4).

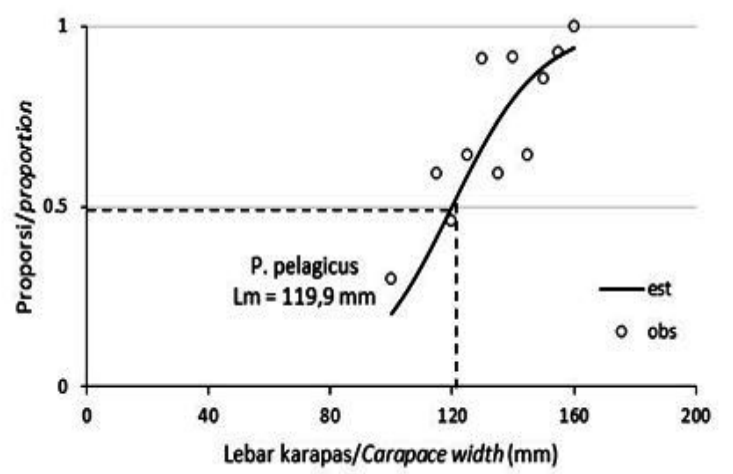

Gambar 3. Rata-rata ukuran tertangkap (Lc) dan matang gonad ( $\mathrm{Lm}$ ) rajungan (Portunus pelagicus) di perairan Kepualauan Aru, 2016.

Figure 3. Length at capture (LC) and length at maturity of blue swimming crab (Portunus pelagicus) in Kepulauan Aru waters, 2016. 


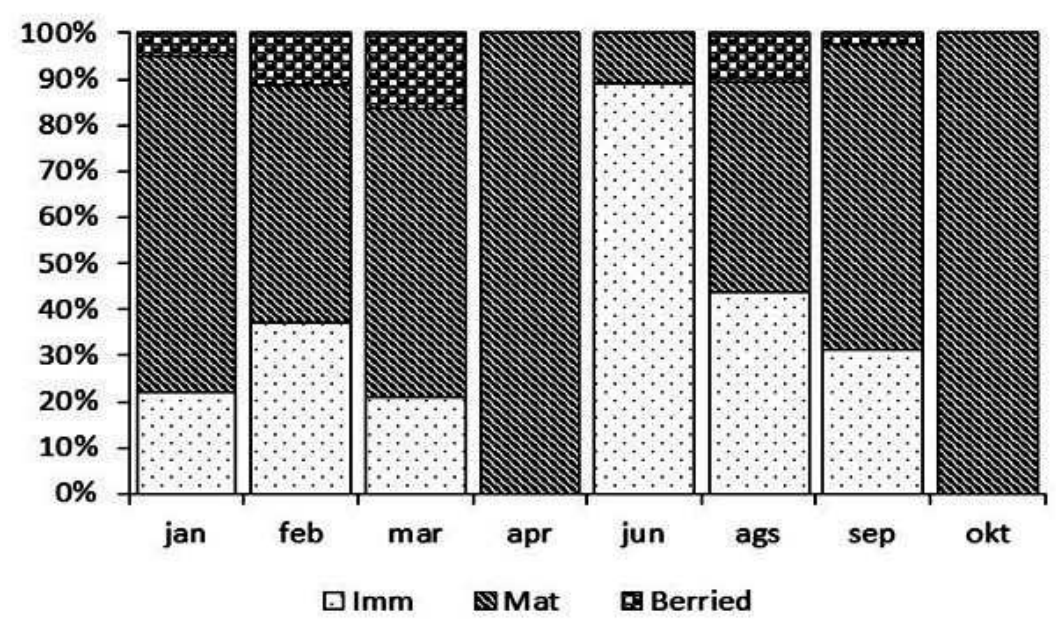

Gambar 4. Sebaran bulanan persentase rajungan betina matang gonad dan membawa telur di perairan Kepulauan Aru, 2016.

Figure 4. Monthly distribution of blue swimming crab mature and berried female in Kepulauan Aru waters, 2016.

\section{Laju Pertumbuhan}

Parameter pertumbuhan rajungan diperoleh dari analisis data frekuensi bulanan panjang karapas dengan cara melacak pergeseran modus dalam suatu urutan waktu sesuai dengan kurva pertumbuhan von
Bertalanffy. Hasil analisa menggunakan program ELEFAN diperoleh lebar karapas asimtosis rajungan (CW") sebesar $185 \mathrm{~mm}$ dengan laju pertumbuhan (K) sebesar 1,15 tahun $^{-1}$. Kurva pertumbuhan dan persamaan pertumbuhan rajungan di perairan Kepulauan Aru disajikan pada Gambar 5.

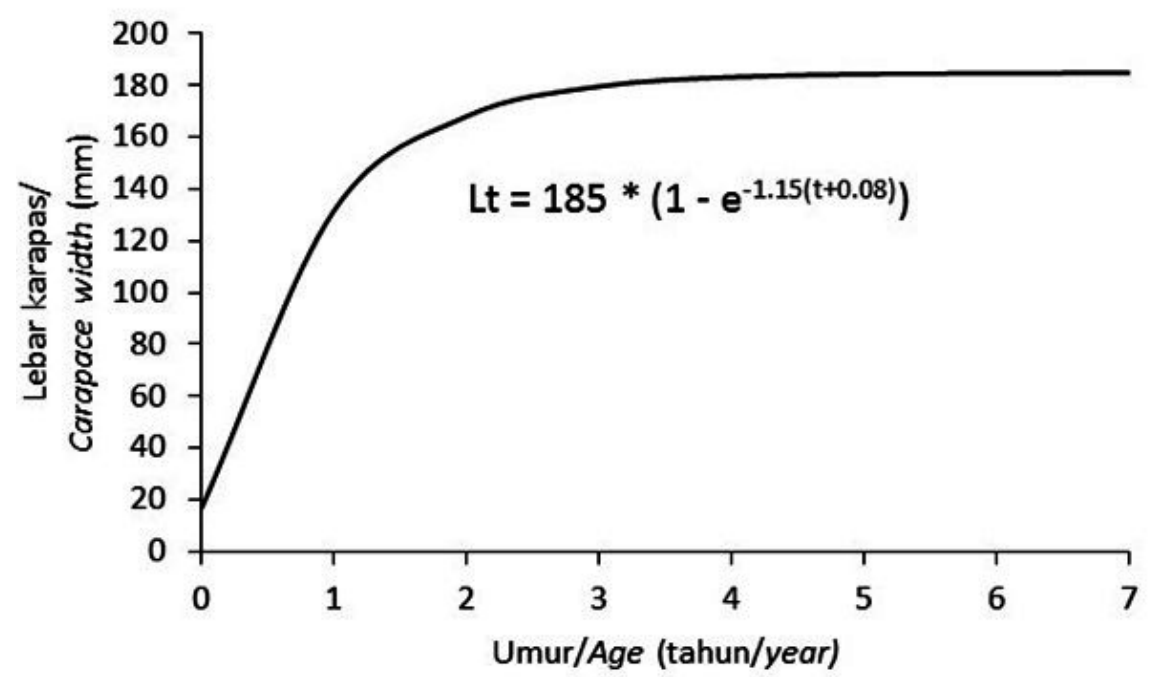

Gambar 5. Kurva dan persamaan pertumbuhan rajungan di perairan Kepulauan Aru, 2016.

Figure 5. Growth curve and formula of blue swimming crab in Kepulauan Aru waters, 2016.

\section{Laju Kematian dan Eksploitasi}

Laju kematian yang diduga terdiri dari laju kematian total (Z), laju kematian alami (M) dan laju kematian akibat penangkapan $(\mathrm{F})$. Laju kematian total diestimasi dari kurva hasil tangkapan yang sudah dilinierkan dengan menggunakan parameter pertumbuhan (Gambar 6). Hasil analisis diperoleh laju kematian total (Z) sebesar 4,94 tahun ${ }^{-1}$, laju kematian alami (M) sebesar 1,20 tahun $^{-1}$ dan laju kematian penangkapan $(F)$ sebesar 3,74 tahun $^{-1}$. Laju eksploitasi (E) rajungan diperoleh sebesar 0,76. 


\section{Length-Converted Catch Curve}

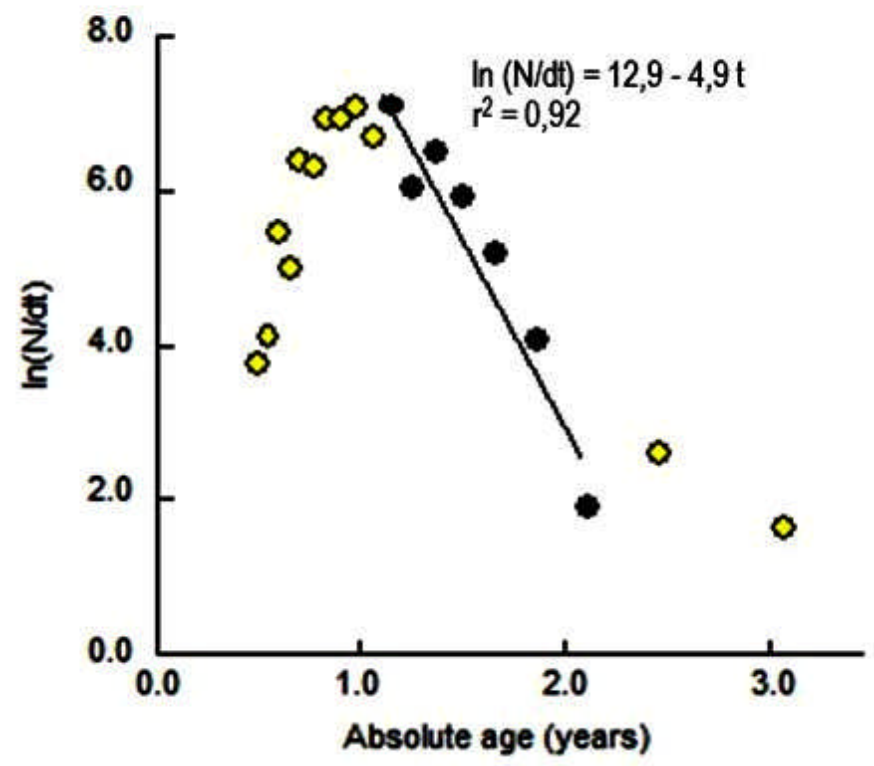

Gambar 5. Kurva hasil tangkapan rajungan yang dilinierkan di perairan Kepulauan Aru, 2016.

Figure 5. Linierized catch curve blue swimming crab in Kepulauan Aru waters, 2016.

\section{Bahasan}

Pada penelitian ini diperoleh kisaran lebar karapas rajungan yang tertangkap jantan antara $92,5-183$ $\mathrm{mm}$ dengan rata-rata $136 \pm 15,5 \mathrm{~mm}$ dan betina 92,5 $-181 \mathrm{~mm}$ dengan rata-rata $141 \pm 16 \mathrm{~mm}$. Rata-rata ukuran rajungan pada penelitian ini lebih besar dibandingkan dengan yang diperoleh di perairan Pati (pantai utara Jawa) yaitu jantan $123,36 \mathrm{~mm}$ dan betina $124,88 \mathrm{~mm}$ (Ernawati, 2013). Perbedaan tersebut disebabkan oleh faktor lingkungan dan tekanan penangkapan yang berbeda di masing-masing lokasi penelitian. Hasil penelitian ini juga menunjukkan bahwa pada Januari dan Juni rajungan yang tertangkap memiliki ukuran yang lebih besar dibandingkan bulan-bulan lainnya. Fenomena ini diduga terjadi karena rajungan yang tertangkap pada bulan-bulan tersebut adalah rajungan-rajungan yang sudah dewasa yang telah matang gonad maupun yang telah melepas telur-telurnya.

Ukuran pada saat mencapai kematangan gonad merupakan parameter populasi yang dianggap sebagai indikator ketika individu telah mencapai tahap dewasa (Soares \& Peret, 1998 dalam Pinheiro \& Lins-Oliveira, 2006). Pengukuran ini berperan penting dalam pengelolaan perikanan mengingat bahwa eksploitasi harus mampu membiarkan sejumlah tertentu indukinduk biota laut yang mempunyai ukuran sama atau lebih dari ukuran tersebut pada saat mencapai kematangan (Sudjastani, 1974).
Hasil penelitian rajungan di Kepulauan Aru menunjukkan bahwa ukuran rata-rata rajungan yang tertangkap (CWc) di perairan ini sebesar 133,4 mm dan rata-rata ukuran matang gonad $(\mathrm{CWm})$ pada lebar karapas 119,9 mm. Hasil penelitian rajungan di perairan lainnya seperti di perairan Pati ditemukan rata-rata ukuran tertangkap dan matang gonad rajungan masing-masing sebesar $108 \mathrm{~mm}$ dan 107 mm (Ernawati et al., 2014), di perairan Timur Lampung rata-rata tertangkap pada lebar karapas 95,5 $\mathrm{mm}$ (jantan) dan 99,4 mm (betina) dan matang gonad pada lebar karapas $103 \mathrm{~mm}$ (Zairion, 2015; Zairion et al., 2015), di perairan Belitung rata-rata ukuran tertangkap pada lebar karapas $93 \mathrm{~mm}$ dan mencapai ukuran matang gonad pada lebar karapas $118,98 \mathrm{~mm}$ (Ernawati et al., 2015). Ukuran rata-rata tertangkap dan matang gonad rajungan di perairan Kepulauan Aru lebih besar dibandingkan perairan-perairan lainnya. Kondisi ini menunjukkan bahwa tekanan penangkapan di perairan ini lebih rendah dibanding perairan Pati, Timur Lampung, dan Belitung. Tekanan penangkapan yang tinggi dapat menyebabkan perubahan struktur populasi yang berdampak pada perubahan dalam strategi reproduksi sumber daya rajungan, sehingga untuk mempertahankan keberlanjutan populasinya, rajungan bereproduksi pada ukuran yang relatif masih kecil (Ernawati et al., 2015). Hasil penelitian di Kepulauan Aru ini juga menemukan bahwa ukuran rata-rata tertangkap rajungan lebih besar dari pada ukuran rata-rata matang gonad $(\mathrm{CWc}>\mathrm{CWm})$. Hal ini mengindikasikan bahwa kondisi rajungan di perairan 
ini masih cukup baik karena kondisi penangkapan masih menunjang proses rekrutmen.

Pengamatan musim pemijahan rajungan dilakukan dengan mengamati sebaran persentase individu betina yang membawa telur (eggs berried female). Hasil penelitian menunjukkan bahwa rajungan cenderung memijah sepanjang tahun yang diindikasikan dengan dominannya rajungan yang matang gonad (TKG 3 dan 4) dan mencapai puncaknya pada Februari-Maret dan Agustus-September. Hasil penelitian Zairion (2015) di perairan Timur Lampung juga menemukan dua puncak musim pemijahan yaiu pada April-Juni dan September-Oktober/November. Selanjutnya puncak pemijahan di perairan Pati terjadi pada Oktober (Ernawati, 2013) dan di perairan Brebes pada JanuariMaret dan Juni-Agustus (Sunarto, 2012). Puncak musim pemijahan rajungan di beberapa lokasi perairan Indonesia tidak jauh berbeda dengan yang diperoleh pada penelitian ini. Fenomena ini diduga terjadi karena pengaruh iklim terutama suhu perairan, dimana pada bulan-bulan tersebut suhu perairan sangat optimal untuk rajungan melakukan pemijahan (Potter \& de Lestang, 2000).

Analisis parameter populasi rajungan dengan tidak membedakan jenis kelaminnya diperoleh laju pertumbuhan (K) sebesar 1,15 tahun $^{-1}$ dengan lebar karapas asimtosis (CW") $185 \mathrm{~mm}$. Nilai K rajungan pada penelitian ini tidak jauh berbeda dengan yang diperoleh di perairan Indonesia lainnya seperti di perairan Bone yakni rajungan jantan sebesar 1,27 tahun $^{-1}$ dan rajungan betina sebesar 1,08 tahun $^{-1}$ (Kembaren et al., 2012), perairan Pati diperoleh untuk rajungan jantan sebesar 1,26 tahun ${ }^{-1}$ dan rajungan betina sebesar 1,13 tahun $^{-1}$ (Ernawati, 2013), perairan Belitung diperoleh untuk rajungan betina sebesar 1,02 tahun $^{-1}$ (Ernawati et al., 2015), perairan Timur Lampung diperoleh untuk rajungan jantan sebesar 1,2 tahun $^{-1}$ dan betina sebesar 1,1 tahun ${ }^{-1}$ (Zairion, 2015). Nilai K yang lebih randah diperoleh pada rajungan yang terdapat di perairan Teluk Lasongko yaitu 0,69 (Hamid et al., 2016). Nilai K yang lebih besar daripada 1 menunjukan bahwa rajungan memiliki pertumbuhan yang relatif cepat dan ini terjadi hampir disebagian besar wilayah perairan tropis. Namun demikian, rendahnya laju pertumbuhan rajungan di perairan Lasongko diduga disebabkan oleh tingginya tingkat eksploitasi di perairan tersebut.

Nilai CW" pada penelitian ini cenderung lebih besar dibandingkan lokasi perairan Bone yaitu $159 \mathrm{~mm}$ (jantan) dan 154 mm (betina) (Kembaren et al., 2012). Selanjutnya di perairan Belitung diperoleh lebar karapas kelamin betina sebesar 180,25 mm (Ernawati et al., 2015) dan perairan Teluk Lasongko sebesar 173,04 mm (Hamid et al., 2016). Bila dibandingkan dengan yang diperoleh di perairan Pati yaitu $185 \mathrm{~mm}$ (jantan) dan $187 \mathrm{~mm}$ (betina) (Ernawati, 2013), maka nilai CW" pada penelitian ini cenderung sama dan lebih rendah dibandingkan dengan rajungan di perairan Timur Lampung yaitu 189,5 mm (jantan) dan 191,5 $\mathrm{mm}$ (betina) (Zairion, 2015).

Perbedaan parameter pertumbuhan rajungan ini disebabkan oleh perbedaan kondisi lingkungan perairan dan tekanan penangakapan di masing-masing lokasi. Ketersediaan pakan alami yang mencukupi di habitatnya akan menyebabkan pertumbuhan rajungan relatif cepat karena persediaan energi yang dibutuhkakan untuk melakukan proses-proses metabolisme tercukupi. Tekanan penangkapan yang tinggi menyebabkan terganggunya proses pertumbuhan rajungan. Hartnoll (1982) menyatakan bahwa pertumbuhan krustasea dipengaruhi oleh faktor internal yaitu jenis kelamin, tingkat kematangan gonad dan anggota tubuh yang hilang, serta faktor eksternal seperti ketersediaan makanan, cahaya, salinitas, suhu dan parasit.

Laju kematian total (Z) rajungan di perairan Aru ini sebesar 4,94 tahun ${ }^{-1}$, laju kematian alami (M) sebesar 1,20 tahun $^{-1}$, dan laju kematian penangkapan (F) sebesar 3,74 tahun ${ }^{-1}$. Laju kematian $(Z, M, F)$ rajungan pada penelitian ini lebih besar dibandingkan dengan yang diperoleh di perairan Teluk Lasongko, dimana diperoleh nilai Z sebesar 3,42 tahun $^{-1}$, nilai M sebesar 0,87 tahun $^{-1}$, dan nilia F sebesar 2,55 tahun ${ }^{-1}$ (Hamid et al., 2016). Namun cenderung lebih kecil bila dibandingkan dengan yang diperoleh di perairan Pati, dimana nilai $Z$ rajungan jantan sebesar 6,19 tahun ${ }^{-1}$ dan rajungan betina sebesar 6,24 tahun $^{-1}$, nilai $M$ rajungan jantan sebesar 1,18 tahun $^{-1}$ dan rajungan betina sebesar 1,27 tahun $^{-1}$, serta nilai $F$ rajungan jantan sebesar 4,97 tahun $^{-1}$ dan rajungan betina 5,01 tahun $^{-1}$ (Ernawati, 2013). Demikian halnya dibandingkan dengan laju kematian rajungan di perairan Bone (Kembaren et al., 2012), dimana nilai Z diperoleh sebesar 6,9 tahun $^{-1}$ (jantan) dan 9,21 tahun $^{-1}$ (betina), nilai F sebesar 1,21 tahun $^{-1}$ (jantan) dan 1,33 tahun $^{-1}$ (betina), serta nilai $F$ sebesar 5,69 tahun $^{-1}$ (jantan) dan sebesar 7,88 tahun $^{-1}$ (betina). Nilai parameter laju kematian rajungan di perairan Aru ini cenderung sama dengan yang diperoleh di perairan Timur Lampung (Zairion, 2015) yakni nilai Z sebesar 4,08 tahun $^{-1}$ (jantan) dan 4,83 tahun $^{-1}$ (betina), nilai $F$ sebesar 1,17 tahun $^{-1}$ (jantan) dan 1,23 tahun $^{-1}$ (betina), serta nilai $F$ sebesar 2,85 tahun $^{-1}$ (jantan) dan 3,66 tahun $^{-1}$ (betina). 
Laju kematian rajungan akibat penangkapan di perairan Kepulauan Aru ini lebih besar tiga kali lipat daripada laju kematian alaminya. Hal ini menunjukkan bahwa tekanan penangkapan rajungan di perairan Kepulauan Aru cenderung tinggi. Laju kematian karena penangkapan tergantung dan bervariasi menurut keragaman upaya penangkapan setiap tahunnya. Variasi laju kematian total ( $Z$ ) dari tahun ke tahun banyak dipengaruhi oleh laju kematian karena panangkapan, sedangkan laju kematian alami tidak terlalu besar variasinya. Laju kematian alami meliputi berbagai macam peristiwa seperti kematian karena predasi, penyakit, dan ketuaan (Rumrill, 1990; Sparre \& Venema, 1999). Sedangkan laju kematian akibat penangkapan lebih bervariasi karena lebih dipengaruhi oleh variasi dan banyaknya upaya penangkapan.

Laju eksploitasi $(E)$ rajungan pada penelitian ini diperoleh sebesar 0,76 . Nilai laju eksploitasi ini cenderung tinggi $(>0,5)$ dan hal yang sama juga ditemukan pada lokasi perairan lainnya seperti yang diperoleh di perairan Timur Lampung (Zairion, 2015) dimana niali E sebesar 0,7 (jantan) dan 0,76 (betina), di perairan Teluk Lasongko (Hamid et al., 2016) diperolen nilai $E$ sebesar 0,75 . Namun bila dibandingkan dengan yang diperoleh di perairan Teluk Bone (Kembaren et al., 2012) dan di perairan Pati (Ernawati, 2013), nilai E di periaran Kepulauan Aru ini lebih kecil, dimana di perairan Bone diperoleh nilai E sebesar 0,82 (jantan) dan 0,86 (betina) dan di perairan Pati diperoleh nilai $E$ sebesar 0,80 (jantan) dan 0,81 (betina). Kriteria dari Pauly (1983) menyatakan bahwa nilai laju pengusahaan yang rasional dan lestari di suatu perairan berada pada nilai $E<0,5$ atau paling tinggi pada nilai $E=0,5$. Nilai laju eksploitasi rajungan di Kepulauan Aru dan di berbagai lokasi perairan lainnya menunjukkan kondisi yang sudah melebihi potensi lestari atau lebih tangkap $(E>0,5)$. Nilai laju ekploitasi yang diperoleh bertolak belakang dengan rata-rata ukuran rajungan yang tertangkap dan matang gonad, dimana ukuran yang tertangkap lebih besar dari ukuran mencapai kematangan gonad. Pada umumnya, laju eksploitasi yang tinggi menyebabkan ukuran yang tertangkap berukuran lebih kecil (Ernawati et al., 2015). Namun hal yang berbeda diperoleh pada penelitian ini yaitu fenomena dominannya rajungan ukuran besar yang tertangkap. Fenomena ini dapat menyebabkan terjadinya penurunan jumlah stok pemijah (spawner) yang pada akhirnya dapat mengakibatkan terjadinya tangkap lebih rekrutmen (recruitment overfishing).

Berdasarkan uraian kajian biologi populasi diatas, dapat disampaikan bahwa pengelolaan perikanan rajungan di perairan ini perlu dilakukan secara hati- hati karena tingkat laju ekploitasi rajungan sudah melebihi tingkat potensi lestari dan terdapat kecenderungan terjadinya penurunan jumlah stok pemijah. Upaya pengelolaan yang dapat di tempuh adalah dengan menerapkan sistem penutupan musim penangkapan (closed-season system). Penutupan aktivitas penangkapan rajungan dapat dilakukan pada saat terjadinya puncak musim pemijahan yaitu pada Februari-Maret dan Agustus-September. Penutupan musim penangkapan ini ditujukan untuk memberikan kesempatan kepada stok pemijah untuk melakukan proses regenerasi sehingga rekrutmen rajungan dapat mendukung ketersedian stok sumberdaya rajungan yang pada akhirnya akan mendukung keberlanjutan hasil tangkapan rajungan di perairan Kepulauan Aru ini. Dengan demikian diharapkan pemanfaatan sumberdaya rajungan dapat berlangsung secara terus menerus (sustainable).

\section{KESIMPULAN}

Sebaran ukuran lebar karapas rajungan (Portunus pelagicus) yang tertangkap di perairan Kepulauan Aru diperoleh nilai rata-rata sebesar $136 \mathrm{~mm}$ untuk jantan dan $141 \mathrm{~mm}$ untuk betina. Rajungan yang tertangkap pada Januari dan Juni memiliki rata-rata ukuran yang lebih besar. Rata-rata rajungan yang tertangkap sudah melawati ukuran matang gonad $(C W c=133,4 \mathrm{~mm}>$ $\mathrm{CWm}=119,9 \mathrm{~mm}$ ). Puncak musim pemijahan terjadi pada Februari-Maret dan Agustus-September. Lebar karapas asimtosis (CW") sebesar $185 \mathrm{~mm}$ dengan laju pertumbuhan (K) 1,15 tahun $^{-1}$ serta laju kematian total (Z) 4,94 tahun ${ }^{-1}$, laju kematian alamiah (M) 1,20 tahun $^{-1}$ serta laju kematian akibat penangkapan (F) 3,74 tahun $^{-1}$. Laju eksploitasi sudah berada pada kondisi lebih tangkap $(E=0,76)$. Hasil kajian menunjukkan bahwa pengelolaan perikanan rajungan perlu dilakukan secara hati-hati agar keberlanjutan sumberdaya dapat lestari. Salah satu upaya yang dapat di tempuh adalah dengan menerapkan sistem penutupan musim penangkapan rajungan pada saat terjadinya puncak musim pemijahan yaitu pada Februari-Maret dan Agustus-September. Dengan demikian diharapkan proses regenerasi dan rekrutmen rajungan selalu dapat mendukung ketersedian stok sumberdaya rajungan yang pada akhirnya akan membawa pada pemanfaatan yang lestari.

\section{PERSANTUNAN}

Tulisan ini merupakan kontribusi dari kegiatan Penelitian Karakteristik Biologi Perikanan, Habitat Sumberdaya dan Potensi Sumberdaya Ikan di WPP 718 - Perairan Laut Aru dan Laut Arafura di Balai Penelitian Perikanan Laut, Jakarta tahun anggaran 2016. 


\section{DAFTAR PUSTAKA}

Beddington, J. R. \& Kirkwood, G. P. (2005). The estimation of potential yield and stock status using life-history parameters. Philosophical Transactions of the Royal Society B. 360(1453), 163-170.

Dinas Kelautan dan Perikanan Kepulauan Aru. (20122016). Stastik perikanan tangkap kabupaten Kepulauan Aru. Dinas Kelautan dan Perikanan. Diterbitkan setiap tahun.

Ernawati, T. (2013). Dinamika populasi dan pengkajian stok sumberdaya rajungan (Portunus pelagicus Linnaeus) di perairan kabupatan Pati dan sekitarnya. Tesis. Bogor: Sekolah Pasca Sarjana, Institut Pertanian Bogor. p 80.

Ernawati, T., Boer, M., \& Yonvitner. (2014). Biologi populasi rajungan (Portunus pelagicus) di perairan sekitar wilayah Pati, Jawa Tengah. BAWAL. 6 (1), 31-40.

Ernawati, T., Kembaren, D. D., \& Wagiyo, K. (2015). Penentuan status stok sumberdaya rajungan (Portunus pelagicus, Linneaues 1758) dengan metode spawning potential ratio di perairan sekitar Belitung. J. Lit Perikan. Ind. 21(2), 63-70.

Gayanilo, F. C. Jr, Sparre, P., \& Pauly, D. (2005). The FAO-ICLARM Stock Assessment Tools II (FiSAT II). Revised Version. User's Guide. FAO Comput. Inf. Ser. Fish. No 8. p 168.

Hartnoll R. G. (1982). Growth. In D.E. Bliess (ed). The Biology of Crustacea. Vol 2, embriology, morfology and genetics. Academic Press. New York. p 111- 196.

Hamid, A., Wardiatno, Y., Lumbabatu, D. J. F., \& Riani, E. (2016). Stock status and fisheries exploitation of blue swimming crab Portunus pelagicus (Linneus 1758) in Lasongko Bay, Central Buton. Asian Fisheries Science. 29: 206-219.

Hermanto, D. T. (2004). Studi pertumbuhan dan beberapa aspek reproduksi rajungan (Portunus pelagicus) di perairan Mayangan, Kabupaten Subang, Jawa Barat. Skripsi. Institut Pertanian Bogor. p 64.

Kailola, P. J., Williams, M. J., Stewart, P. C., Reichelt, R. E., McNee, A., \& Grieve, C. (1993). Australian fisheries resources. Bureau of Resource
Sciences. Department of Primary Industries and Energy, and the Fisheries Research and Development Corporation, Canberra, Australia. $p$ 422.

Kembaren, D. D., Ernawati, T., \& Suprapto. (2012). Biologi dan parameter populasi rajungan (Portunus pelagicus) di perairan Bone dan sekitarnya. J.Lit.Perikan.Ind. 18 (4), $273-281$.

King, M. (1995). Fisheries biology, assessment and management (p. 341). United Kingdom: fishing news books.

Martin, J. W., \& Davis, G. E. (2001). An updated classification of the recent crustacea. No. 39. Science Series Natural History Museum. Los Angeles. p 124.

Morgan, M. J. (2008). Integrating reproductive biology into scientific advice for fisheries management. Journal of Northwest Atlantic Fishery Science. 41, 37-51.

Ng, P. K. L. (1998). Crabs. In Carpenter, K.E. and V.H.Niem (Eds). FAO Species identification guide for fishery purposes. The living marine resources of the Western Central Pacific. FAO-UN. Vol. 2. Rome. p 1045 - 1155.

Pauly, D. (1983). Some simple methods for the assessment of tropical fish stocks. FAO Fisheries Technical Paper. (254) 52.

Pinheiro, A. P. \& Oliveira, J. E. (2006). Reproductive biology of Panulirus echinatus (Crustacea: Palinuridae) from São Pedro and São Paulo Archipelago, Brazil. Nauplius. 14 (2), 89-97.

Potter, I. C. \& de Lestang, S. (2000). Biology of the blue swimmer crab, Portunus pelagicus in Leschenault Estuary and Koombana Bay, South Western Australia. Journal Royal Society of Western Australia 83(4), 443-458.

Rumrill, S. S. (1990). Natural mortality of marine larvae. Ophelia. 32(1-2), 163-198.

Sparre, P. \& Venema, S. (1999). Introduction to Tropical Fish Stock Assesment. (Introduksi Pengkajian Stok Ikan Tropis, alih bahasa: Pusat Penelitian dan Pengembangan Perikanan). Buku 1: Manual. Badan Penelitian dan Pengembangan Perikanan. Jakarta. p 438. 
Sudjastani, T. (1974). Dinamika populasi ikan kembung di Laut Jawa. Laporan Penelitian Perikanan Laut. Balai Penelitian Perikanan Laut, Jakarta. (1), 30-64.

Sumpton, W. D., Potter, M. A., \& Smith, G. S. (1994). Reproduction and Growth of The Commercial Sand Crab, Portunus pelagicus (L.) in Moreton Bay, Queensland. Asian Fisheries Science. 7: $103-$ 113.

Sunarto. (2012). Karakteristik bioekologi rajungan (Portunus pelagicus) di perairan laut Kabuapten Brebes. Disertasi. Bogor: Sekolah Pasca Sarjana, Institut Pertanian Bogor. p 171.

Zairion, Boer M., Wardiatno Y., \& Fahrudin, A. (2014a). Komposisi dan ukuran rajungan (Portunus pelagicus) yang tertangkap pada beberapa stratifikasi batimetri di perairan Lampung Timur. J. Lit Perikan. Ind. 20(4), 199-206.
Zairion, Wardiatno Y., Fahrudin A., \& Boer, M. (2014b). Distibusi spasio-temporal populasi rajungan (Portunus pelagicus) betina mengerami telur di perairan pesisir timur Lampung. BAWAL. 6 (2), 95-102.

Zairion. (2015). Pengelolaan berkelanjutan perikanan rajungan (Portunus pelagicus) di Lampung Timur. Disertasi. Bogor: Sekolah Pasca Sarjana, Institut Pertanian Bogor. p 236.

Zairion, Wardiatno, Y., \& Fahrudin, A. (2015). Sexual maturity, reproductive pattern and spawning female population of the blue swimming crab, Portunus pelagicus (Brachyura: Potunidae) in East Lampung coastal waters, Indonesia. Indian Journal of Science and Technology. 8(7), 596-607. 